\title{
Cultivation of Creative Thinking in Modern Ceramic Art Teaching
}

\author{
Dehua $\mathrm{Yu}$ \\ The Department of Art and Design \\ Hunan City University \\ Yiyang, Hunan, China 413000
}

\begin{abstract}
This paper describes the importance of creative thinking in the teaching of modern ceramic art and the necessity of reform, discusses the cultivation ideas of creative thinking in modern ceramic art teaching and provides a solution to the problem starting from modern ceramic art cultivation program and the current situation of teaching.
\end{abstract}

Keywords-creative thinking; modern ceramic art; teaching reform; cultivation program

\section{INTRODUCTION}

Creative thinking is the necessary ability training of modern art design, product making and other subjects. Among which, creativity is the important course for creative thinking cultivation, providing a systematic learning paradigm. The creation core of modern ceramic art lies in the individuality, the times and sociality of works. Only the creation based on traditional culture and popular culture as well as the reflections on them with the possession of creative thinking can the excellent works that can arouse resonance be generated. How to cultivate students' creative thinking through curriculum teaching and social practice is a topic in modern ceramic art teaching worthy of further study.

\section{IMPORTANCE OF CREATIVE THINKING IN MODERN Ceramic Art Teaching}

Creativity is the spiritual product of divergent thinking, and creative thinking is the spiritual drive for artists and designers to obtain inspiration and express creative solutions. Modern ceramic artistic creation emphasizes the individualized color of works and the emotional expression of individual. Therefore, no matter in creation and in teaching, displaying and explaining modern ceramic art using new thinking, new forms, and new elements is crucial. Nowadays, the world is changing with each passing day. People's life is promoted by all kinds of creativity. The artwork forms are also creating their own time. Only by continuously injecting the innovation consciousness into the teaching of modern ceramic art, can the ceramic artists or ceramic art designers meeting requirements of the times be cultivated. As the creation of artwork, modern ceramic art is the external display of creator's creative thinking, understanding and expression of society and life, and a comprehensive creative behavior of a kind of thought and objective existence. Ceramic designers are no exception, having only differences in references and their inherent logic.
China's modern ceramic art is gradually integrating into the international community, being equipped with more international thinking in terms of both the height of artistic creation and the market it is facing. Once facing the market, the works or products must be differentiated with other works. The enlightening "Chinese, traditional", is to differentiate its own national art language in the final analysis.

It can be seen that the cultivation of creative thinking is very important to the teaching of modern ceramic art. In teaching, we should not only pay attention to the cultivation of artistic quality and theoretical accomplishment, but also shall develop students' creative thinking.

\section{Cultivation Of CREative Thinking In MODERN CERAMIC ART TEACHING}

\section{A. Make Clear Target Positioning.}

As for the teaching of modern ceramic art, its teaching positioning is reflected in three aspects, namely talent cultivation program, the syllabus and Classroom teaching program. Cultivation goal is the important content in its teaching program, which is the standard and guidance of follow-up teaching work. On this basis, in the actual teaching process of modern ceramic art, students' innovative thinking is mainly cultivated through creative practice. Some colleges and universities focus on the cultivation of relevant cultural literacy, but ignore the importance of creative thinking course on ceramic art creation. The courses are cut due to various reasons, Reasons, set up and then cut, which involves the problem of target positioning. As for the employment position of the modern ceramic art graduates from local undergraduate institutions and their job position, teaching objective orientation should clearly offer the development direction of this major in the future, provide targeted cultivation of students' accomplishments and ability, thus to meet the talent needs of relevant enterprises and institutions.

\section{B. Personality Thinking Cultivation}

It is necessary for modern ceramic art teaching to cultivate students' general modeling ability and expression techniques, cultivate students to master the process of ceramic art creation and production, and grasp the general thinking method of design and production, more importantly, students' innovative thinking ability shall be cultivated. There are a variety of 
methods, rich creation materials and complex creation processes for modern ceramic art creation, which requires students to learn and appreciate through practice, and consciously offer the individual innovative ideas. This is an inevitable process of the creation by artists, and some need years of accumulation and understanding. The process can be shortened through relevant teachers' guidance in classroom teaching and practice teaching, so that students can consider and think about problems from more perspectives. Specific to the creative practice, individuality cultivation can be influenced subtly through sketching design at early stage and the discussion in production process. Fully affirm students' thinking expression in the course of discussion and offer appropriate guidance.

\section{Cultivation Structure System}

The cultivation program shall be formulated based on cultivation objective first of all. One same major can be cultivated differently, as the students can be cultivated as talents of enterprises, they can also be cultivated as talents for institutions. There shall be focuses in cultivation program with targeted setting of cultivation structure. Currently, the cultivation program in most of the undergraduate colleges is developed horizontally; in other words, it reaches every aspect, extending in terms of surface, which is lack of threedimensional and depth. For example, the setting of modern ceramic art course, some colleges delete the ergonomics, creative graphics, dimensional composition, design sketch and many others, which is equivalent to cutting off one's hands and feet, let alone creativity. This is a systematic structure. If it is to cultivate industrial workers, then it shall be technologybased. It is enough to have technology, as students can go to the factory to practice and understand slowly. If it is to train designers, cultivation of creative thinking is essential.

\section{Classroom Teaching and Practice}

Enrich students' knowledge accumulation through classroom teaching and develop students' innovative thinking ability through practical activities. Practical activities are the processes that can really stimulate students to think and play freely. Classroom teaching fosters students' cultural knowledge and accomplishment, which complement each other. The demonstration effect of modern ceramic art teaching is especially important. The students know nothing about this major, so teachers' creative thinking directly affects students' creative thinking direction. Therefore, teachers should pay attention to the significance of demonstration in relevant technical teaching process, and provide more channels for learning in the creation process, such as visiting museums, exhibition halls, art exhibitions, etc. as well as opening up appreciation course of masters' ceramic artworks, inviting off campus experts to deliver speeches and other forms, to enrich students' awareness of modern ceramic art, thus to enrich their creative ideas, and not to be limited to the creative thinking of teachers. In addition, teachers can also require students to complete selected subjects in groups through subject design, to increase the interaction between students and students, as well as students and teachers, and to enrich students' understanding and imagination in the course of implementing the selected subjects.
The role of teachers in teaching is undoubtedly crucial, and the teacher's knowledge determines the knowledge of most of the students, the vision of teachers determines the vision of the majority of students, and the teacher's learning habits also directly affect students' learning habits, let alone the teacher's professional skills. Therefore, teachers should improve their own professional qualities, participate in the capacity training of related disciplines, broaden their own knowledge and vision, so as to better guide students to complete the accumulation process of creative thinking knowledge, and promote the development and cultivation of students' creative thinking.

\section{CONCLUSION}

The cultivation of innovative thinking in modern ceramic art teaching always serves the creation of works, and is to enrich the creative thinking of students, cultivate students to consider problems from different angles, find out problems, and understand the problems from a broader vision to express their own opinions. Teachers should strive to stimulate the divergent thinking of students to help students establish the awareness of thinking problems from multiple aspects, so that they can discover their own uniqueness and innovation. The cultivation of innovative thinking requires teachers to actively guide, to do more curriculum setting and project development, to train students' thinking habits through practice. More importantly, a complete cultivation system should be established, to targeted cultivation of relevant ceramic talents with clear objectives. Accurate positioning can make clear the cultivation objectives of this major with appropriate focuses, and can cultivate the elite talents with emphasis, rather than the so-called generalist of various industries who can enter into various departments.

\section{REFERENCES}

[1] Xie Xuemin. On the Ceramic Art Teaching --- How to Improve Students' Creativity in Classroom Teaching Practice [J]. Modern Communication. 2011(12)

[2] Zhang Cao. Reflections on Ceramic Art Teaching in Regular Institution of Higher Learning [J]. CGWORLD. 2014(01)

[3] $\mathrm{Xu}$ Liangjie. Suggestions and Measures for Improving College Students' Innovative Thinking Ability in Art Education [J].Art Education Research. 2011(02) 